\title{
On Developing the Noise Reduction Model for Indonesian Aviation
}

\author{
Aprilia Sakti Kusumalestari ${ }^{1,3, *}$, Santoso Sukirno ${ }^{1}$, Muhammad Suryanegara ${ }^{2}$, Harry Sudibyo ${ }^{2}$ \\ 1 Department of Physics, Faculty of Mathematics and Natural Science, Universitas Indonesia, Kampus Baru \\ UI Depok, Jawa Barat 16424, Indonesia \\ 2 Department of Electrical Engineering, Faculty of Engineering, Universitas Indonesia, Kampus Baru UI \\ Depok, Jawa Barat 16424, Indonesia \\ 3 Faculty of Aeronautical Engineering Department, Aerospace University of Suryadarma, Jl. Protokol Halim \\ Perdanakusuma Komplek Bandara, Halim Perdanakusuma Jakarta Timur 13610, Indonesia \\ * Correspondence: aprilia_sk@yahoo.com
}

Received: 10 August 2019; Accepted: 2 November 2019; Published: 30 December 2019

\begin{abstract}
Aircraft noise exposure is still one of many abandoned pollution problems in Indonesia. The effects on human life have been studied more thoroughly in Europe and other regions. We review how some efforts have been implemented and how others must be further developed to support an integrated solution. Following several studies on noise exposure effects in Indonesia, future research must take part in reducing these effects. Indonesian research on noise reduction should follow the track of international research to develop sustainability and protect human capital. This paper reports the developing work aims for building a noise reduction model in the field of Indonesian aviation.
\end{abstract}

Keywords: noise effect, aircraft noise, noise reduction

\section{Introduction}

The rapidly growing aviation industry in Indonesia contributes to heavy aircraft operation and busy airports. Transportation by plane tends to be faster and generally easier than transportation by other vehicles due to Indonesia's geographic condition. Recently, more than 600 air transport routes have become available for domestic flight. The number of international flights based out of Indonesia is another factor contributing to busy traffic.

This development poses a responsibility; an increase in aircraft operation is followed by an increase in noise pollution. The effects of noise exposure on humans have been studied for many decades, especially in Europe. Cardiovascular disease, cognitive impairment, and other annoyances are reported as side effects of repeated noise exposure. World Health Organization issued a document in 2011 about noise effects on human health. The organization titled the paper "burden disease".

Epidemiological studies suggest a higher risk of cardiovascular disease, including high blood pressure and myocardial infarction, in people chronically exposed to high levels of road or air traffic noise [1]. Additional research specific to studying aircraft noise exposure has been conducted in Europe as well. The group includes a sample of 4,861 people from six countries in Europe who live near airports within a specific perimeter of noise exposure. It has been predicted that these individuals will be affected by aircraft noise exposure due to standard airport activities. Previous research on cardiovascular disease in relation to noise exposure was further studied by analyzing 
the effects of such exposure on a sample of 439 participants. The study's conclusion describes how women are physically more affected by aircraft noise exposure than men [2].

The effects of noise exposure on children include cognitive impairment [1] and decreased hearing capability [3]. The first reference is a review report based on a notable amount of research from around the world. In this report, the World Health Organization (WHO) stated that noise exposure's effects on humans constitute a disease burden. The second reference mentioned above includes a study of noise exposure affecting children who live near Adisucipto International Airport, Yogyakarta. It is also revealed that psychological effects are increased through the General Reaction Score in individuals who live within the perimeter of aircraft noise exposure [4]. The score represents the instability of human emotion. This research focuses on Adisumarmo Airport as the subject of noise exposure, while those individuals who live near the airport are the object affected.

All the noise exposure effects are down streamed as a differentiation between human work productivity and capability. Several countries consider these effects a serious problem [1]. These concerned countries include England, France, the Netherlands, and Germany. Due to the age of productivity, Indonesia, which has acquired bonus demography in the past few decades, should be made aware of the many types of human-inflicted destruction, including the serious effects of noise exposure. The prevention of such destruction should be developed to protect future generations from the smallest risk of decline in quality, productivity, and capability.

This study aims to provide an explanatory review for conceptual research on the topic of noise reduction in Indonesian aircraft design. The objective is to encourage aviation researchers who are interested in the dangerous effects of aircraft noise to actively implement change. The researcher chose a propeller-driven aircraft for the purposes of this study.

\section{Noise Treatment}

In response to an issue regarding scientists' views on noise pollution [5], we propose that noise reduction can be implemented by three different methods. Although noise pollution includes all types, such as industry- and transportation-related noise, the following three methods may be implemented to reduce the effects of aircraft noise, exclusively.

\subsection{Noise Sources}

The first method of scientific effort to reduce aircraft noise involves developing the technology for designing the noise source itself; this is the most effective effort. Aircrafts, as products of technology, generate noise due to their efficiency of power. The power losses appear as heat and sound. The engine should be designed to emit less sound, and the airframe should be designed more aerodynamically; therefore, sound generated by fluid and surface impact may be diminished.

\subsection{Soundwaves}

Another method to reduce noise involves manipulating soundwaves. Scientists use active noise control to cancel the waves of sound, which are identified as noise. This method has been developed in many cases of noise reduction. In modern aircraft technology, active noise control is usually installed for the purpose of reducing noise inside the cabin. This installation is designed to protect passengers from noise generated by the engine just outside the cabin.

\subsection{Exposed Object(s)}

The technology for reducing noise can also be applied through structures of design exposed to noise. In the case of aircraft noise, these structures include airport buildings, runways, and other materials surrounding the runways. 


\subsection{Noise Treatment in Indonesia}

The effects of noise pollution in Indonesia have been studied and reported. According to the three noise reduction methods mentioned above, those studies have not thoroughly covered all the important areas.

Through the Indonesian government, the Ministry of Environment has taken a few noise measurements in major cities surrounding airports, including Soekarno-Hatta International Airport, Hang Nadim Airport (Batam), Syamsudin Noor Airport (Banjarmasin), Sultan Sjarif Kasim (Pekanbaru), and Juanda International Airport (Surabaya) [6]. The reports indicate how noise exposure is passing over the standard of noise limitation, which was released by the Ministry of Environment in 1996. Nevertheless, the follow-up implementation is not entirely applied.

Some researchers in several cities have studied the effects of aircraft noise on individuals living near airports. Adisucipto Airport, which is located in Yogyakarta, was chosen as the subject of research in 2007 [7]. The research collected data from children in at the elementary level who were affected by noise exposure due to their schools being located near an airport. The object divided into two range areas: the first range included children whose schools were located in areas with an average noise exposure of $71.40 \mathrm{dBA}$, while the second range included children whose schools were located in areas with an average noise exposure of $63.40 \mathrm{dBA}$. The conclusion of the research found more than $60 \%$ of children belonging to the first range experienced a decrease in hearing capability, while more than $20 \%$ children belonging to the second range experienced the same.

Adisumarmo Airport, which is located near Surakarta, Central Java, had already been previously chosen as a subject of noise exposure study. In 2010, noise exposure from the airport was indicated as a cause of increased general reaction scores [8]. The score is psychologically defined as a scale of human unsteadiness. The conclusion indicates that there was aircraft noise level significantly affected the difference in scores for women who live near Adisumarmo Airport. It is noteworthy to mention that the women affected by noise exposure may be more emotional than women who have not been affected by noise exposure.

Technology for aircraft design has not been largely applied in the Indonesian aviation industry, nor has the study of noise reduction by advancing aircraft design been significantly implemented. According to the international research development on this subject, Indonesia has a basic for improving the research. Applying propeller-driven aircraft model produce by Indonesian manufacturer is a good starting point.

The second method for reducing noise (manipulating sound waves), is applied in the aircraft manufacturing industry in Indonesia. Active noise control must be installed inside the cabin to cancel noise waves in areas of the cabin near the propellers to provide the passengers with comfortable volume levels.

The third method, reducing noise for exposed objects, poses another challenge for the Indonesian aviation industry. These challenges include the airport itself and the areas surrounding the airport. The perimeter of the area can be roughly defined by measuring the distance from the end of runways. Officially, the area affected by airport noise exposure may be defined by measuring the airport activity that is regulated by authority.

\section{Noise Sources in Aircraft Design}

The study of aircraft noise began in the early 1960s, when the operation of many jet engine aircrafts began implementation. Since the topic covers aircraft noise, the noise sources include both engine and airframe. Noise generated by the engine is produced by the fan/propeller, nacelle, and exhaust. On the other hand, noise from the airframe is generated by aerodynamic phenomena, where low viscosity fluid flows down a surface with high velocity.

Aircraft noise abatement was constrained by the international regulation. International Civil 
Aviation Organization (ICAO) initially issued a regulation for aircraft noise in the Annex 16, Volume 1 of ICAO Standard on Environmental Protection [10]. The standard was primarily issued to the Chicago Convention in 1978 and was developed through different implementation in various countries or regions. Europe is the leading region for improving the standard, as it regards noise pollution as a very important issue. The concern regarding this standard involves the protection of human capital against deficiency of health performance or productivity.

According to the explanation above, aircraft design has gone through several stages of both developing and improving quietness during transportation, from the engine as a main source of aircraft noise to the airframe as a minor source. The latter becomes significant when applied to modern aircrafts with a high bypass ratio engine.

Parts of the engine that contribute significant noise include every assembly of blades, such as the propeller, inlet fan, compressor, and turbine. Other sources include the combustion chamber, nacelle, and exhaust. Blade theory is necessary for studying the main parts of an engine. This is a basic theory involving aerodynamics that are developed to increase efficiency, sharpen effectiveness, and reduce noise. The theory defines an effective geometry of blades, density, frequency, and additional variables. All these variables will vary depending on the function of the blades. Blades that are designed as part of the propeller engine will be different than blades that are designed as inlet inside turbofan engine.

The technology for designing an engine to be quieter has been developed by engine manufacturers. One example includes an engine manufacturer who develops research on jet noise reduction. This is not an easy goal to achieve due to the requirement of constrain imposed by the engine and aircraft system. Reducing jet noise will decrease those two factors [11].

Exhaust jet noise with a high speeded gas burst already generates high noise. The noise is increased when cool flow due to bypass mixes with hot flow from the combustion chamber. The factory has developed a technology to make this mixed process quieter. The technology design includes jet exhaust by the form of chevron, as seen in Figure. 1. This design will reduce jet noise by making the mixing process slighter.

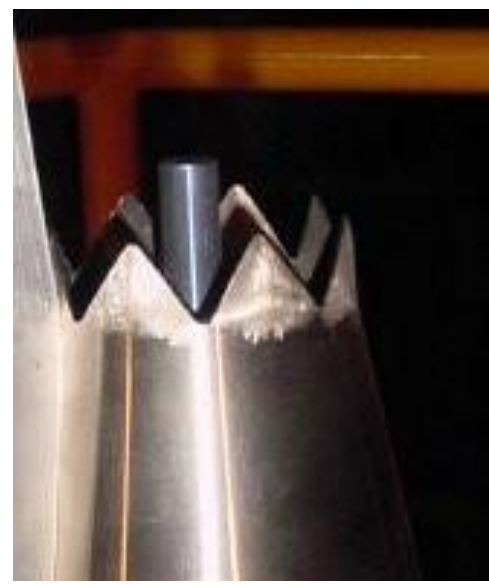

Figure 1. Chevron exhaust engine designed to reduce jet noise [11]

An example of fan blade design innovation is introduced by another engine manufacturer; the design includes a hollow fan blade to increase efficiency and reduce noise. A hollow blade reduces the average density, therefore reducing the required power and amount of noise generated. Figure. 2 describes the technological development of aircraft engines for the purpose of reducing noise. A noise level of 120 EPNdB (Effective Perceived Noise decibel) appeared in the earliest technology for aircraft jet engines. By designing the engine through high bypass turbofan technology, the noise may 
be reduced significantly over a period of 30 years. The progress after a period of 50 years includes about $30 \mathrm{EPNdB}$ of aircraft noise reduction; these are the engines installed on modern aircrafts of the $21^{\text {st }}$ century.

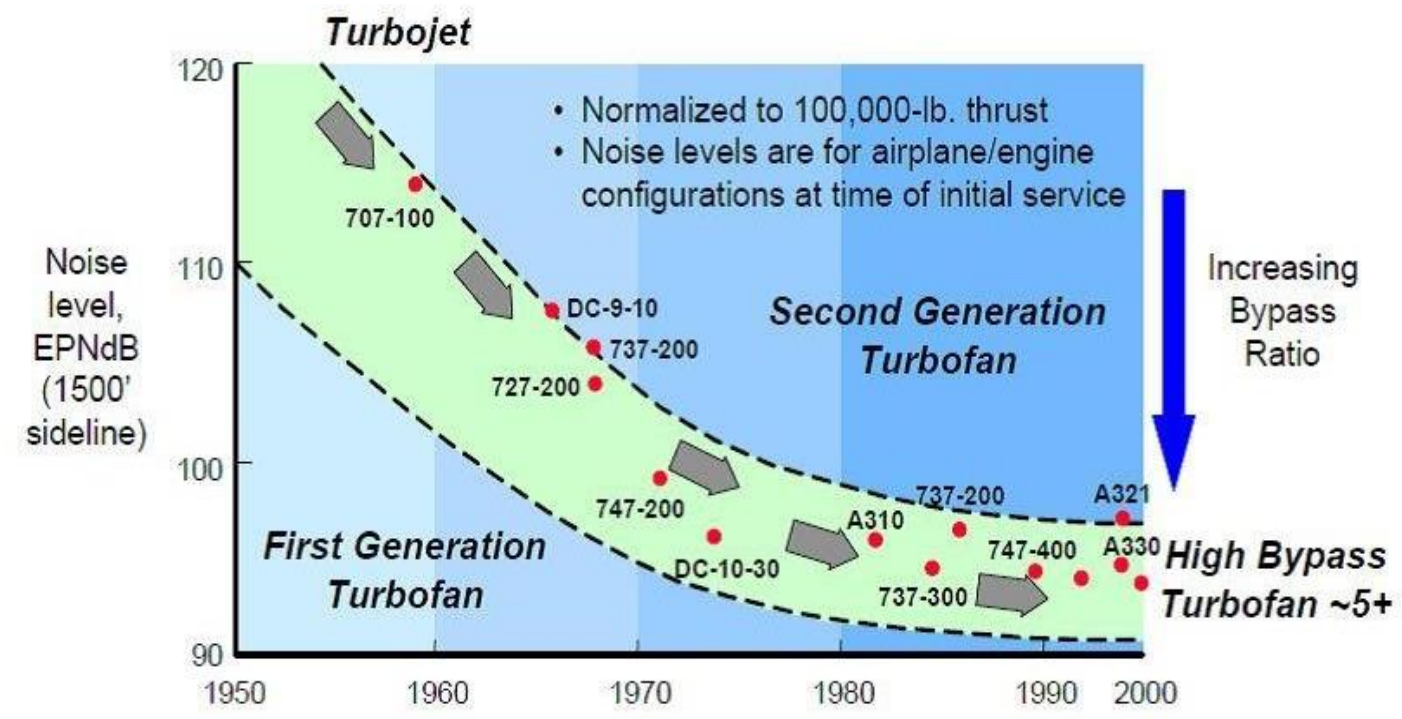

Figure 2. Technology development of an aircraft engine and its technical performance on noise level [11]

The design of the engine nacelle has also been recorded by many studies as effectively reducing aircraft noise. The research shows improvements in material technology and geometry design. An example of material design includes the use of metallic foam.

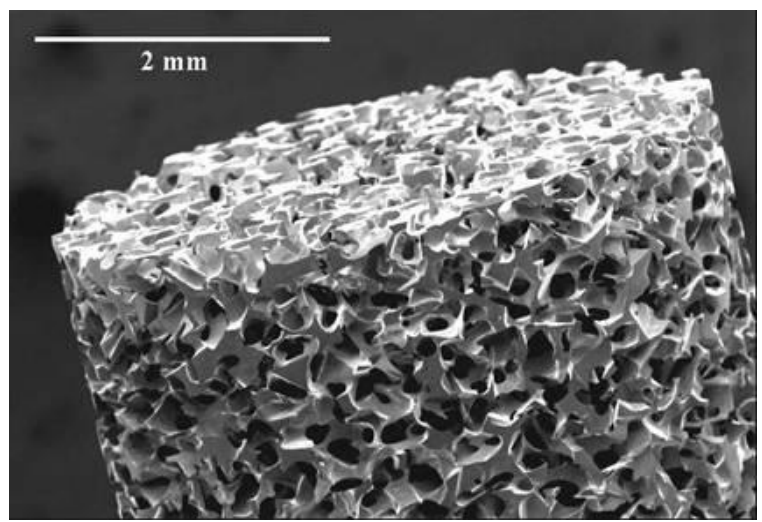

Figure 3. Metallic foam technology airframe reduces [12]

According to many studies conducted by industries and universities alike, the airframe contributes significantly to aircraft noise, especially to aircrafts with high bypass ration engine [12]. The research is divided by three sections of noise sources: landing gear, high lift devices, and another subsection of the airframe.

Landing gear is one of the noisiest sections of the airframe. Extended research for landing gear may be conducted by designing a model to scale for identifying the specific noise it emits. The model should be designed to operate similarly to actual landing gear. Noise exposure of the model can be measured by a test section of an appropriate wind tunnel. The tunnel should include acoustic treatment and should be sized properly. High-lift devices are the second noisiest portion of the airframe. The wing section with a combination shape of airfoil, flap, and slat generates an aerodynamic noise source. High velocity of airflow blows between each part. Reducing noise in the 
section is also a big challenge. Noise reduction technology is applied by adding a slat-cove-cover [12], as shown in Figure. 4. This cover prevents airflow from blowing between the main wing and slat, therefore effectively diverting noise.

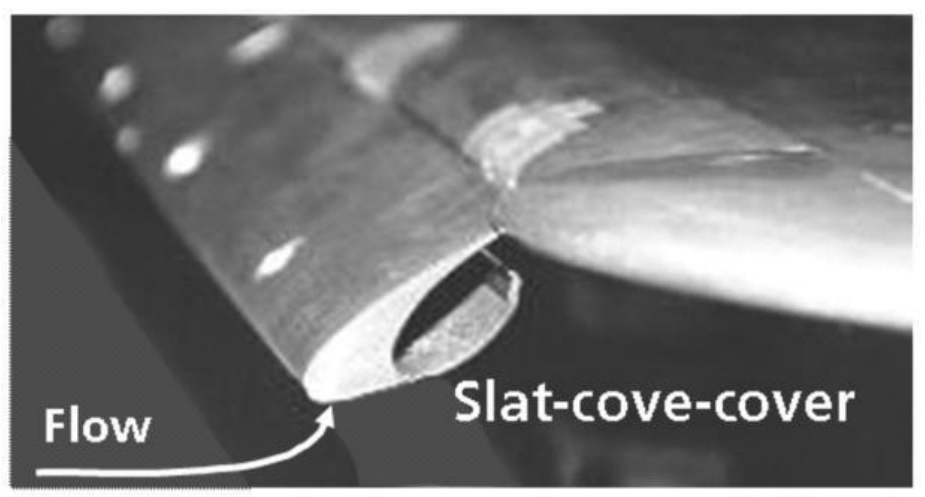

Figure 4. Slat-cove-cover material reduces aerodynamical noise in a high-lift device [12]

\section{Research Framework}

A framework of research is defined according to the objective of this study. The framework covers research on noise treatment that can be applied in Indonesian aircraft design. The treatment in this framework consists of identifying and reducing noise from specific sources.

Recently, aircraft manufacturers in Indonesia have produced propeller-driven aircrafts. This production appears to have been due to domestic traffic demand. Since the object includes propeller driven aircrafts, the research may be improved by further studying noise treatment of the propeller, airframe, and other parts of the aircraft that contribute large amounts of noise. Aside from considering most noise contributors, the research can approach the easiest objects first, then follow by addressing more difficult ones.

In fact, there are engines that have not yet been produced in Indonesia whose object as a noise reduction source shall begin from airframe design. Identification of specific aircrafts will be studied, and attenuation of the noise emission will be modeled. The output of the model is expected to be applied to the industry and contribute toward reducing noise exposure. According to recent studies, the main noise contributor of the airframe is landing gear. The following study will set landing gear of a propeller-driven aircraft as the object, as presented in Table 1.

Table 1. Research Framework on Aircraft Noise Reduction

\begin{tabular}{|c|c|c|c|c|c|}
\hline \multirow{2}{*}{ 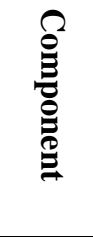 } & \multicolumn{2}{|c|}{ airframe } & \multicolumn{3}{|c|}{ engine } \\
\hline & $\begin{array}{c}\text { landing } \\
\text { gear }\end{array}$ & HLD & $\begin{array}{l}\text { main } \\
\text { engine }\end{array}$ & exhaust & nacelle \\
\hline \multirow{3}{*}{ 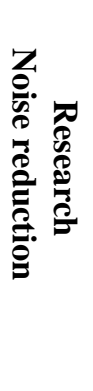 } & \multicolumn{2}{|c|}{$\begin{array}{l}\text { manually modeled and } \\
\text { experimented }\end{array}$} & $\begin{array}{l}\text { bypass } \\
\text { ratio }\end{array}$ & \multicolumn{2}{|c|}{ shape } \\
\hline & \multicolumn{2}{|c|}{$\begin{array}{l}\text { software modeled and } \\
\text { experimented }\end{array}$} & \multicolumn{2}{|c|}{$\begin{array}{c}\text { material } \\
\text { development }\end{array}$} & material \\
\hline & \multicolumn{2}{|c|}{$\begin{array}{c}\text { software modeled, } \\
\text { 3D-printed experiment }\end{array}$} & $\begin{array}{l}\text { blade } \\
\text { design }\end{array}$ & $\begin{array}{c}\text { mixing } \\
\text { hot \& cold } \\
\text { flow }\end{array}$ & $\begin{array}{c}\text { metallic } \\
\text { foam }\end{array}$ \\
\hline
\end{tabular}




\section{Conclusion}

This paper has covered the developing work aims for Indonesian aviation in building aircrafts with the goal of reducing noise. We have reviewed a framework that conducted a study on reducing aircraft noise in Indonesian aviation industry. Noise exposure should be a major concern of all Indonesian individuals, and the objective of protecting citizens from even minor hearing damage is important. Several studies have been discussed and will serve as a basis for advanced research. Future research on aircraft noise exposure in Indonesia can be executed by following the direction of existing research conducted in many countries and companies around the world. Since aircraft engines were not initially designed in Indonesia, aircraft noise research should analyze the design of aircrafts by studying airframe as a starting point for future research. This research may be further developed to obtain results that may contribute to the scientific interest of Indonesian aircraft design. The model for noise reduction will be initially implemented by designing the landing gear of small propeller-driven aircrafts. By developing further research, the model may be modified and empirically used for other types of aircrafts.

\section{Acknowledgment}

This study was supported by University of Indonesia with Program of Hibah PITTA 2019. The program lead by Dr. Santoso Soekirno with number of contract NKB-0663/ UN2.RK3.1/ HKP.05.00/2019.

\section{References}

[1] World Health Organization (WHO) (Regional Office for Europe) and JRC European

Commission 2010 Burden of disease from environmental noise A reference

[2] Selander J, et al. 2009 for HYENA Consortium, Saliva cortisol and exposure to aircraft noise in six European countries Environmental Health Perspective

[3] Sutopo M N, Rianto B U D and Ng N 2007 Hubungan antara intensitas kebisingan aktifitas penerbangan di Bandara Adi Sucipto dengan nilai ambang batas pendengaran pada anak Berita Kedokteran Masyarakat

[4] Eko E and dan Hartono W 2010 Studi tentang general reaction score pada wanita yang mengalami stress bising pesawat udara di sekitar bandara adi sumarmo boyolali Jurnal Ekosains (Solo)

[5] Ruggiero A 2016 Noise pollution: what the scientific community can do? Environment Pollution and Climate Change Journal

[6] Sarana P and Lingkungan P D 2011 Laporan pengkajian kebisingan di sekitar Bandara di beberapa kota besar di Indonesia Kementerian Lingkungan Hidup

[7] Sutopo M N, Rianto B U D and Ng N 2007 Hubungan antara intensitas kebisingan aktivitas penerbangan di Bandara Adi Sucipto dengan nilai ambang pendengaran pada anak Berita Kedokteran Masyarakat (UGM: Yogyakarta)

[8] Hartono E W 2010 Studi tentang general reaction score pada wanita yang mengalami stress bising pesawat udara di sekitar Bandara Adi Sumarmo Boyolali Jurnal Ekosains (Solo) 
[9] Sance B, Jah M, Dan N A 2017 Pemodelan kebisingan akibat aktifitas pesawat dan optimalisasi kebisingan di bandara juanda dengan menggunakan model Les Frair Jurnal Sains Dan Seni ITS pp. 2337-3520 (2301-928X)

[10] ICAO Aircraft noise to the convention on international civil aviation Environmental Protection

[11] Leylekian L, Lebrun M, Lempereur P 2014 An overview of aircraft noise reduction technologies Journal Aerospace Lab

[12] Dobrzynski W 2010 Almost 40 years of airframe noise research: what did we achieve? Journal of Aircraft pp 353-67

(C) 2019 by the authors. Submitted for possible open access publication under the terms and conditions of the Creative Commons Attribution (CC BY) license (http://creativecommons.org/licenses/by/4.0/). 